\title{
Radiology, Soft Tissue
}

National Cancer Institute

\section{Source}

National Cancer Institute. Radiology, Soft Tissue. NCI Thesaurus. Code C18989.

A specialty concerned with the use of $x$-ray and other forms of radiant energy in the diagnosis and treatment of disease of soft tissue. 